\title{
UPAYA MENINGKATKAN KEMAMPUAN MELAKUKAN OPERASI HITUNG YANG MELIBATKAN BERBAGAI BENTUK PECAHAN BAGI SISWA KELAS V DENGAN PROBLEM BASED LEARNING MODEL
}

\author{
Sarip Hidayat \\ SDN IBU DEWI VII \\ sariphidayat@gmail.com
}

Diterima: 30 Juni 2018

\begin{abstract}
ABSTRAK
Penelitian ini memakai model PBL (Problem Based Learning) dengan harapan akan mendorong peserta didik dalam meningkatkan pemahaman dalam melakukan operasi hitung yang melibatkan berbagai bentuk pecahan, melatih menyelesaikan suatu masalah yang dihadapi juga membiasakan belajar kelompok melalui penelitian ini diharapkan guru dapat meningkatkan kreativitasnya dalam menentukan model pembelajaran yang sesuai dengan konsep, tujuan dan kondisi peserta didik. Pelaksanaan Penelitian terdiri dari dua siklus. Pada siklus Pertama belum ada peningkatan yang berarti, ini disebabkan peserta didik masih belum terbiasa menyelesaikan suatu masalah dengan kerja kelompok, sedangkan pada siklus Kedua peserta didik mulai terbiasa menyelesaikan tugas secara kelompok dengan adanya kerjasama dalam mengerjakan tugas dengan baik. Hal ini bisa terlihat dari pencapaian aktivitas siswa mengalami peningkatan sebesar $18,60 \%$, aktivitas guru mengalami peningkatan sebesar $14 \%$, dan kemampuan kognitif peserta didik juga mengalami peningkatan sebesar 6,3\%, dan prosentase ketuntasan pun mengalami peningkatan sebesar 14,63\%. Dari hasil pelaksanaan Siklus I dan Siklus II dapat disimpulkan bahwa penggunaan model PBL (Problem Based Learning) dapat meningkatkan kemampuan melakukan operasi hitung yang melibatkan berbagai bentuk pecahan pada siswa Kelas V SDN Ibu Dewi VII Cianjur.
\end{abstract}

Kata Kunci : Model Problem Based Learning, pemahaman

\section{PENDAHULUAN}

Dalam pembelajaran matematika guru banyak mengeluh atas rendahnya kemampuan peserta didik dalam melakukan operasi hitung yang melibatkan berbagai bentuk pecahan. Hal ini dikarenakan kesalahan pemahaman konsep matematika sehingga dalam pengerjaan soal-soal latihan banyak yang salah dan mengakibatkan prestasi belajar siswa rendah.

Pembelajaran berbasis masalah dapat merangsang berpikir tingkat tinggi dengan situasi berorientasi pada masalah, termasuk didalamnya belajar bagaimana belajar. Terkait dengan KTSP, pembelajaran dengan pemberian tugas secara berkelompok menjadi salah satu pendekatan yang sebaiknya dikuasai oleh guru baik teoritis maupun praktis. 
Adapun rumusan masalahnya yaitu apakah model Problem Based Learning meningkatkan kemampuan melakukan operasi hitung yang melibatkan berbagai bentuk pecahan bagi siswa kelas V?

\section{Pembelajaran Berbasis Masalah}

Pembelajaran berbasis masalah sebagai rangkaian aktivitas pembelajaran yang menekankan pada proses penyelesaian masalah secara ilmiah (Wina S, 2006 hal 214) . Sedangkan Arend (2004) memberikan rincian tentang tahapan dalam Problem Based Learning seperti tercantum di tabel berikut :

Tabel 1 Tahapan dalam $P B L$.

\begin{tabular}{|c|c|}
\hline Fase & Aktivitas guru \\
\hline$\frac{\text { Fase 1: }}{\text { Mengorientasikan siswa pada masalah }}$ & $\begin{array}{l}\text { Menjelaskan tujuan pembelajaran, logistik yang } \\
\text { diperlukan , memotivasi siswa terlibat aktif pada } \\
\text { aktivitas pemecahan masalah yang dipilih }\end{array}$ \\
\hline $\begin{array}{l}\text { Fase 2: } \\
\text { Mengorganisasi siswa untuk belajar }\end{array}$ & $\begin{array}{l}\text { Membantu siswa membatasi dan mengorganisasi tugas } \\
\text { belajar yang berhubungan dengan masalah yang dihadapi }\end{array}$ \\
\hline $\begin{array}{l}\text { Fase 3: } \\
\text { Membimbing penyelidikan individu } \\
\text { maupun kelompok }\end{array}$ & $\begin{array}{l}\text { Mendorong siswa mengumpulkan informasi yang sesuai, } \\
\text { melaksanakan eksperiman, dan mencari untuk penjelasan } \\
\text { dan pemecahan }\end{array}$ \\
\hline $\begin{array}{l}\text { Fase 4: } \\
\text { Mengembangkan dan menyajikan } \\
\text { hasil karya }\end{array}$ & $\begin{array}{l}\text { Membantu siswa merencanakan dan menyiapkan karya } \\
\text { yang sesuai laporan, video, dan model, dan membantu } \\
\text { mereka untuk berbagi tugas dengan temannya }\end{array}$ \\
\hline $\begin{array}{l}\text { Fase 5: } \\
\text { Menganalisa dan mengevaluasi proses } \\
\text { pemecahan masalah }\end{array}$ & $\begin{array}{l}\text { Membantu siswa melakukan refleksi terhadap } \\
\text { penyelidikan dan proses-proses yang digunakan selama } \\
\text { berlangsungnya pemecahan masalah. }\end{array}$ \\
\hline
\end{tabular}

(Nurhadi dan Senduk, 2003:59)

\section{METODOLOGI PENELITIAN}

Objek penelitian adalah siswa kelas $\mathrm{V}$ dengan jumlah peserta didik 35 orang semester genap tahun pelajaran 2016-2017 dengan kompetensi dasar melakukan operasi hitung yang melibatkan berbagai bentuk pecahan.

Penelitian Tindakan Kelas dilaksanakan melalui dua siklus, untuk melihat perkembangan hasil belajar dan aktivitas peserta didik dalam mengikuti mata pelajaran matematika dengan model Problem Based Learning. Adapun pelaksanaannya disesuaikan dengan jadwal yang telah dibuat. Siklus I dan II terdiri dari Perencanaan, Pelaksanaan, Pengamatan, dan Refleksi.

Instrumen yang digunakan yaitu tes tertulis dan lembar observasi. Teknik analisis dilakukan secara sederhana dengan membandingkan rata-rata persentase hasil tes. 


\section{HASIL DAN PEMBAHASAN}

\section{Observasi Aktivitas Peserta Didik Siklus 1}

Hasil observasi aktivitas peserta didik pada siklus 1 dapat dilihat pada tabel 2 dan grafik berikut .

Tabel 2

Perolehan Skor Aktivitas Peserta Didik dalam Penilaian Proses Siklus 1

\begin{tabular}{|c|c|c|c|c|c|c|}
\hline \multirow[t]{2}{*}{ No } & \multirow{2}{*}{$\begin{array}{c}\text { Nama } \\
\text { Kelompok }\end{array}$} & \multicolumn{4}{|c|}{ Aspek yang dinilai } & \multirow{2}{*}{$\begin{array}{l}\text { Jml } \\
\text { skor }\end{array}$} \\
\hline & & Keaktifan & Kerjasama & Ketertiban & Ketelitian & \\
\hline 1 & Mawar & 8 & 7 & 6 & 6 & 27 \\
\hline 2 & Melati & 8 & 8 & 6 & 6 & 28 \\
\hline 3 & Raflesia & 7 & 6 & 6 & 5 & 24 \\
\hline 4 & Teratai & 7 & 7 & 7 & 6 & 27 \\
\hline 5 & Anggrek & 6 & 6 & 6 & 5 & 23 \\
\hline \multicolumn{2}{|c|}{ Jumlah Skor } & 36 & 34 & 31 & 28 & \\
\hline \multicolumn{2}{|c|}{ Skor Maksimal } & 50 & 50 & 50 & 50 & \\
\hline \multicolumn{2}{|c|}{ \% Pencapaian } & $72 \%$ & $68 \%$ & $62 \%$ & $56 \%$ & \\
\hline \multicolumn{2}{|c|}{ Kriteria Keberhasilan } & Baik & Cukup & Cukup & Kurang & \\
\hline
\end{tabular}

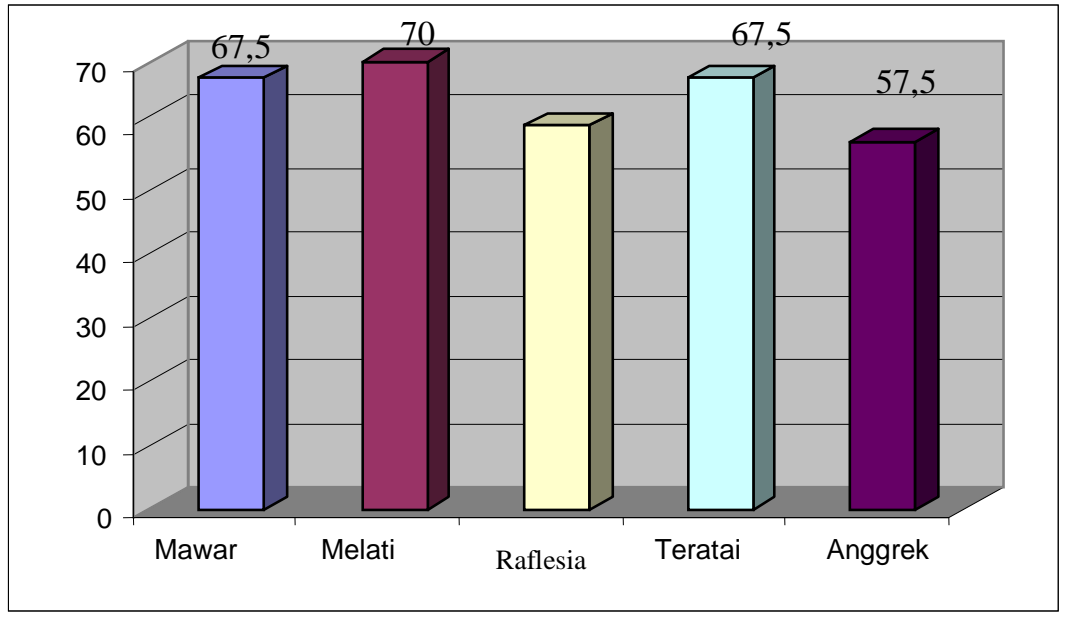

\section{Gambar 1}

Aktivitas Peserta Didik Setiap Kelompok di Siklus 1

Gambar 1 menunjukan perolehan skor aktivitas peserta didik tiap kelompok. Aktivitas tertinggi dicapai oleh kelompok Melati dengan skor 28 atau 70\% dengan kriteria keberhasilan Baik. Aktivitas terendah dicapai oleh kelompok angrek dengan skor 23 atau 57,5\% dengan kriteria keberhasilan Kurang. Hasil rata-rata yang diperoleh dari setiap 
kelompok menunjukan perlu adanya peningkatan aktivitas agar mencapai kriteria keberhasilan baik.

\section{Observasi Aktivitas Guru Siklus 1}

Hasil observasi aktivitas guru dalam pembelajaran pada siklus pertama dapat dilihat pada tabel berikut.

Tabel 3

Hasil Observasi Aktivitas Guru pada Siklus 1

\begin{tabular}{|c|c|c|c|c|c|c|c|}
\hline \multirow[t]{2}{*}{ No } & \multirow{2}{*}{ Aspek yang dinilai } & \multicolumn{5}{|c|}{ Skor } & \multirow[t]{2}{*}{ Ket } \\
\hline & & 1 & 2 & 3 & 4 & 5 & \\
\hline 1. & $\begin{array}{l}\text { Kegiatan Awal } \\
\text { - Menyiapkan alat peraga, media dan sumber belajar } \\
\text { - Memberikan apersepsi }\end{array}$ & & & & $\begin{array}{l}\checkmark \\
\checkmark\end{array}$ & & \\
\hline 2 & $\begin{array}{l}\text { Kegiatan Inti } \\
\text { - Memulai Pembelajaran } \\
\text { - Melaksanakan Pembelajaran yang sesuai tujuan } \\
\text { - Menjelaskan materi ajar } \\
\text { - Menggunakan sumber belajar yang sesuai } \\
\text { - Keruntutan pelaksanaan pembelajaran } \\
\text { - Pengelolaan waktu pembelajaran secara efektif }\end{array}$ & & & $\begin{array}{l}\checkmark \\
\checkmark \\
\checkmark\end{array}$ & $\begin{array}{l}\checkmark \\
\checkmark \\
\checkmark \\
\checkmark\end{array}$ & & \\
\hline 3 & $\begin{array}{l}\text { Kegiatan Akhir } \\
\text { - Melaksanakan Evaluasi } \\
\text { - Melakukan tindak lanjut }\end{array}$ & & & $\checkmark$ & $\checkmark$ & & \\
\hline & Jumlah Skor & & & & 37 & & \\
\hline & Skor Maksimal & & & & 50 & & \\
\hline & \% Capaian & & & & $74 \%$ & & \\
\hline & Kriteria Keberhasilan & & & & $\overline{\text { Baik }}$ & & \\
\hline
\end{tabular}

Dari tabel 3 dapat dilihat bahwa Guru masih kurang memberi kesempatan pada peserta didik dalam membuat soal-soal latihan yang sesuai.

\section{Observasi Aktivitas Peserta Didik Siklus 2}

Hasil observasi aktivitas peserta didik pada siklus 2 dapat dilihat pada gambar berikut.

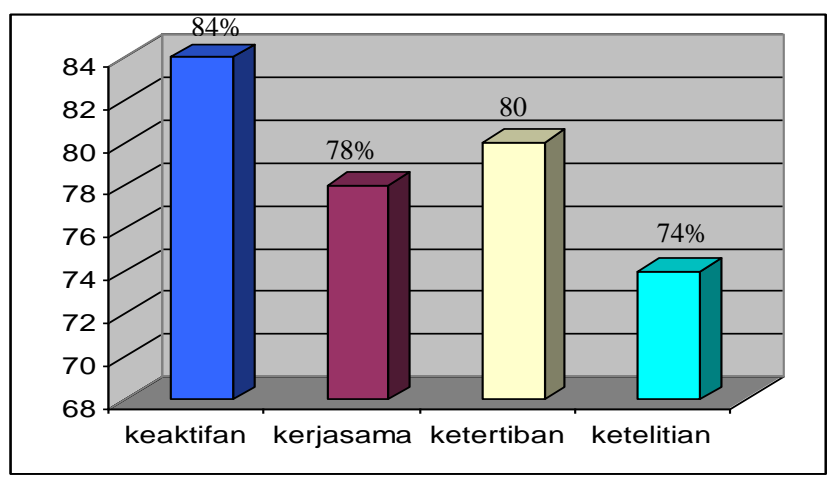

Gambar 2

Aktivitas Peserta Didik pada Siklus II 
Gambar 2 menunjukkan capaian aktivitas peserta didik pada setiap aspek. Aktivitas peserta didik tiap kelompok pada siklus II menunjukkan banyak peningkatan.

\section{Observasi Aktivitas Guru Siklus 2}

Hasil observasi aktivitas guru dalam pembelajaran pada siklus II mengalami peningkatan. Guru sudah menunjukkan peningkatan aktivitas, hal ini sangat berpengaruh kepada aktivitas siswa sehingga ikut menunjukkan peningkatan hasil belajar yang memuaskan.

Sesuai hasil analisis pada siklus II didapat temuan sebagai berikut :

a. Peserta didik sudah tidak asing dengan model Problem Based Learning dan peserta belajar kelompok.

b. Pada setiap kelompok sudah terlihat keaktifan yang sangat baik.

c. Pencapaian kompetensi kognitif peserta didik juga mengalami peningkatan di siklus I Nilai rata-rata mencapai 66,4 (cukup) sedangkan nilai rata-rata pada siklus II mencapai $72,7 \%$ (baik) dengan peningkatan sebesar $6,3 \%$ selain nilai rata-rata meningkat juga persentase ketuntasan di siklus I mencapai $73,52 \%$ menjadi $88,15 \%$ pada siklus II dengan peningkatan sebesar $14,62 \%$, dan persentase ketidaktuntasan pada siklus I mencapai $26,48 \%$ sedangkan pada siklus II mencapai 10,85\% ini mengalami penurunan sebesar $15,63 \%$ dan ini menunjukkan peningkatan dalam pemahaman konsep materi pada operasi bilangan pecahan biasa dan pecahan campuran.

\section{KESIMPULAN}

Sesuai hasil Penelitian Tindakan yang telah dilaksanakan untuk mencapai tujuan penelitian dan rumusan masalah, maka dapat disimpulkan sebagai berikut :

1. Nilai aktivitas peserta didik dalam penilaian proses pada siklus I rata-rata mencapai $64,5 \%$ (cukup) sedangkan pada siklus II meningkat menjadi rata-rata 79,5\% (baik). sedang aktivitas guru pada siklus I rata-rata mencapai 74\% (baik) sedangkan pada siklus II meningkat menjadi rata-rata $88 \%$ (baik sekali).

2. Penilaian kognitif peserta didik pada siklus I mencapai nilai rata-rata $66,4 \%$ (cukup) dan pada siklus II mengalami kemajuan menjadi rata-rata $72,7 \%$ (baik), ini menunjukkan peningkatan pemahaman peserta didik pada operasi hitung yang melibatkan berbagai bentuk pecahan dengan Problem Based Learning Model.

3. Dengan model PBL peserta didik lebih tertantang lagi berfikir agar dapat menyelesaikan suatu masalah karena model PBL ini dapat melatih dan 
mengembangkan kemampuan yang dimiliki oleh peserta didik dan dapat menciptakan suasana kondusif, terbuka, demokrasi dan menyenangkan

\section{REFERENSI}

Wina, S. (2006). Strategi Pembelajaran. Jakarta: Kencana.

Nurhadi, A. G. S. (2003). Pembelajaran Konstektual (Contextual Teaching and Learning ICTL). Malang: Universitas Negeri Malang.

BNSP. (2006). Petunjuk Teknis Pengembangan Silabus dan contoh/model Silabus. Jakarta: Depdiknas

A.Tabrani Rusyan. (2003). Pedoman Mengajar Matematika Berdasarkan KBK untuk Sekolah Dasar. Bandung: PT Inti Media.

Dahar, R.W. (1989). Teori-teori Belajar. Jakarta: Erlangga.

Ruseffendi. (1988). Pembelajaran Matematika menurut Pandangan Konstruktivis. Jakarta: Erlangga. 